\title{
Synthesis and properties of conjugated polymers from 3,6-di(4-chlorophenyl)-3,6-dihydrophthalic acid diethyl ester and application to the photo-sensitizer of a solar cell
}

\author{
Atsushi Morikawa and Hirotoshi Kakuta \\ $\mathrm{Ni}(0)$-catalyzed coupling polymerizations of 3,6-di(4-chlorophenyl)-3,6-dihydrophthalic acid diethyl ester 1 were accompanied \\ by isomerization of the 1,4-cyclohexadiene moiety into a 3,5-cyclohexadiene group, yielding a conjugated polymer. The \\ structure of this conjugated polymer was the same as that of the conjugated polymer from 3,6-di(4-chlorophenyl)-1,2- \\ dihydrophthalic acid diethyl ester 2 . The number-average degree of polymerization was only $\sim 7$ due to the low solubility of the \\ conjugated polymer. The conjugated polymer exhibited a $\lambda$ max at $430 \mathrm{~nm}$ in the absorption spectrum, and could be applied \\ as a photo-sensitizer of a solar cell. The incident monochromatic photon $(450 \mathrm{~nm})$-to-current conversion efficiencies of \\ photocurrent from an indium-titanium oxide (ITO)/ $/ \mathrm{TiO}_{2}$ electrode modified with the conjugated polymer was $6.1 \%$ in the \\ $\mathrm{I}_{3}{ }^{-}-3 \mathrm{I}^{-}$electrolyte wet system. The conjugated polymer exhibited a glass transition temperature of $210^{\circ} \mathrm{C}$ and was \\ converted by thermal treatment at $300{ }^{\circ} \mathrm{C}$ to poly( $p$-phenylene) (PPP) with the elimination of ethoxycarbonyl groups. \\ Polymer Journal (2013) 45, 790-796; doi:10.1038/pj.2012.228; published online 30 January 2013
}

Keywords: conjugated polymers; 3,6-di(4-chlorophenyl)-1,2-dihydrophthalic acid diethyl ester; 3,6-di(4-chlorophenyl)-3,6-dihydrophthalic acid diethyl ester; Ni(0)-catalyzed coupling polymerizations; photo-sensitizer of a solar cell

\begin{abstract}
INTRODUCTION
Conjugated polymers are of great inherent interest for the development of optical and electronic applications because of the extended $\pi$-electron delocalization along their backbone. However, a problem in the synthesis of conjugated polymers is their insolubility due to their rigid backbones. For example, direct polymerization of benzene using electrochemical or chemical oxidation techniques only produces oligomers as a result of the inherent insolubility of the growing polyphenylene chains (these chains have number-average degrees of polymerization (DP) of $15-20) .{ }^{1}$ Soluble $\pi$-conjugated polymers with alkyl or alkyloxy substituents were synthesized, ${ }^{2-4}$ with representative examples being poly([2-methoxy-5-(2-ethylhexyloxy)-1,4phenylenevinylene $])^{5}$ and poly(3-hexylthiophene). ${ }^{6-7}$ Higher molecular weight conjugated polymers without substituents were obtained by an indirect method that involved the synthesis of a soluble non-conjugated precursor followed by its chemical transformation into a conjugated polymer. Additionally, poly $(p-$ phenylene)s were synthesized via 1,3-cyclohexadiene derivative routes ${ }^{8-13}$ and poly(phenylenevinylene)s and poly(thienylene vinylene)s were synthesized via the Gilch, ${ }^{14}$ Wessling-Zimmerman
\end{abstract}

precursor, ${ }^{15-16}$ thexanthate precursor ${ }^{17}$ and the sulphinyl precursor routes. ${ }^{18-20}$ The elimination of low molecular weight compounds, such as hydrogen, halogens, acetic acid and dithiocarbamate, accompanied all of the conversions of precursor non-conjugated polymers to conjugated polymers. 3,6-diphenyl-3,6-dihydrophthalic acid dimethyl ester 3, a non-conjugated compound, was converted to 3,6-diphenyl-1,2-dihydrophthalic acid dimethyl ester 4, a conjugated compound (Scheme 1a). ${ }^{21}$

In this study, we examined the preparation of a conjugated polymer by a two-step procedure involving the synthesis of a non-conjugated polymer and its subsequent conversion to a conjugated polymer. The synthesis of $\mathbf{P 1}$ by $\mathrm{Ni}(0)$-catalyzed coupling polymerizations ${ }^{22-26}$ of 3,6-di(4-chlorophenyl)-3,6-dihydrophthalic acid diethyl ester 1 (Scheme $1 \mathrm{~b}$ ) and the conversion of the non-conjugated polymer P1 to the conjugated polymer P2 (Scheme 1d) were examined. P2 was directly synthesized from 2 for comparison (Scheme 1c). As the elimination of low molecular weight compounds does not accompany the conversion of $\mathbf{P} \mathbf{1}$ to $\mathbf{P} \mathbf{2}$, this conversion is expected to proceed under mild conditions. The conjugated polymer $\mathbf{P} \mathbf{2}$ was characterized by ${ }^{1} \mathrm{H}$ NMR (nuclear magnetic resonance), absorption spectroscopy, 

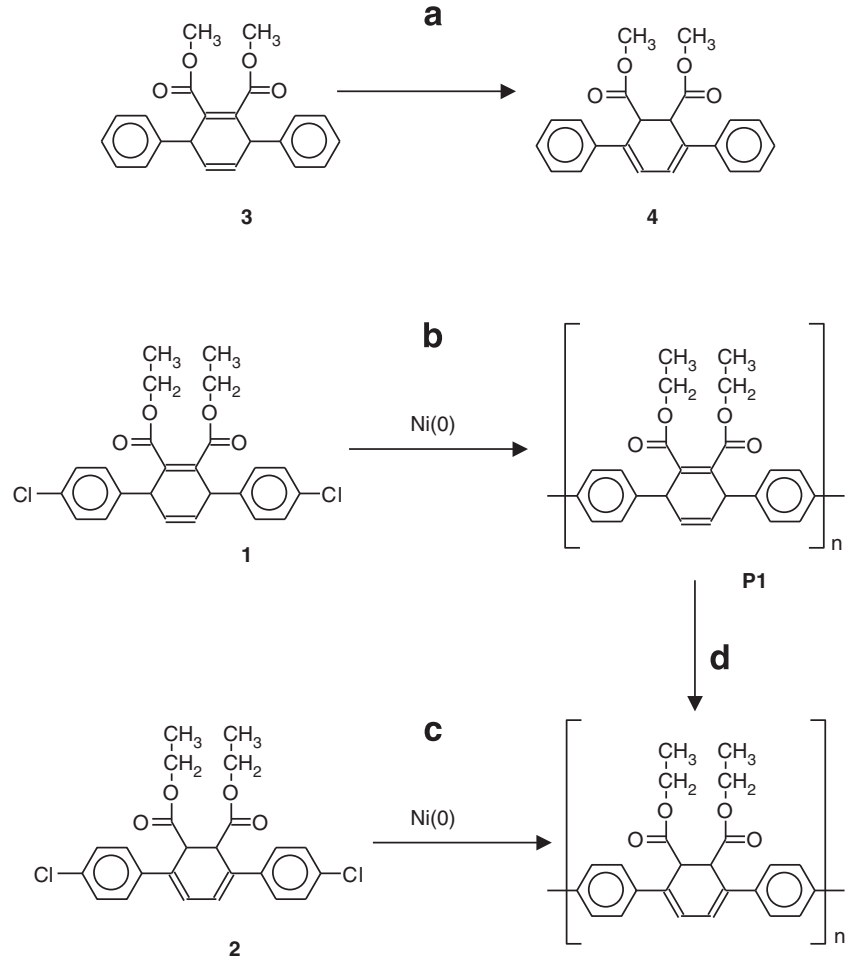

P2

Scheme 1 (a) Isomerization of 3 into 4. (b) $\mathrm{Ni}(0)$-catalyzed polymerization of $\mathbf{1}$. (c) $\mathrm{Ni}(0)$-catalyzed polymerization of 2 . (d) Isomerization of nonconjugated polymer into conjugated polymer.

differential scanning calorimetry (DSC) and thermogravimetry (TG), and investigated for applications as a photo-sensitizer of solar cells. ${ }^{27}$ As $p$-terphenyls have been reported to be easily prepared by oxidative decarboxylation of 3,6-diphenyl-1,2 dihydrophthalic acid derived from $4,{ }^{21}$ the conversion of $\mathbf{P} 2$ to poly( $p$-phenylene) was also investigated.

\section{EXPERIMENTAL PROCEDURE}

Materials

$\mathrm{NiCl}_{2}\left(\mathrm{PPh}_{3}\right)_{2}$ (Cotton et al. ${ }^{24}$ ) was purchased from Aldrich (Milwaukee, WI, USA). $\mathrm{NiBr}_{2}, \mathrm{NiCl}_{2}$, triphenylphosphine, $\mathrm{Et}_{4} \mathrm{NI}$, 4-chlorobenzaldehyde, acetaldehyde, 4-chlorobenzylchloride, acetylenedicarboxylate, sodium and phenol were purchased from Wako Pure Chemical Industries (Osaka, Japan) and used as received. Toluene and dioxane were freshly distilled over sodium benzophenone ketyl under a nitrogen atmosphere before use. $\mathrm{N}$-Methyl-2-pyrrolidone (NMP), $\mathrm{N}, \mathrm{N}$-dimethylformamide (DMF) and $\mathrm{N}, \mathrm{N}$ dimethylacetamide were purchased from Kanto Chemical Co., Inc. (Tokyo, Japan), and freshly distilled over calcium hydride. $\mathrm{NaCl}$, acetonitrile, tetrapropylammonium iodide, $\mathrm{KI}$ and $\mathrm{I}_{2}$ were purchased from Wako Pure Chemical Industries and used as received.

3,6-Di (4-chlorophenyl)-3,6-dihydrophthalic acid diethyl ester (1) A solution of $(E, E) 1,4$-bis(4-chlorophenyl)-1,3-butadiene $(5.50 \mathrm{~g}, 0.02 \mathrm{~mol})$ and diethyl acetylenedicarboxylate $(10.2 \mathrm{~g}, 0.06 \mathrm{~mol})$ in phenol $(30 \mathrm{ml})$ was heated at reflux temperature for $1 \mathrm{~h}$. After the reaction mixture was cooled to $80^{\circ} \mathrm{C}$, the phenol was evaporated under reduced pressure of 15-20 torr. Pure $\mathbf{1}$ was obtained by recrystallization from ethanol. The yield was $5.79 \mathrm{~g}$ (65\%), while the Mp was $96-98^{\circ} \mathrm{C}$. The infrared (IR) spectrum exhibited absorption bands at $2980 \mathrm{~cm}^{-1}$, $2930 \mathrm{~cm}^{-1}\left(-\mathrm{C}_{2} \mathrm{H}_{5}\right), 1720 \mathrm{~cm}^{-1}(\mathrm{C}=\mathrm{O}), 1615 \mathrm{~cm}^{-1}$ and $1600 \mathrm{~cm}^{-1}(\mathrm{C}=\mathrm{C})$.<smiles>CCOC(=O)C1=C(C(=O)OCC)C(C)(c2ccc(Cl)cc2)C(C)=CC1c1ccc(Cl)cc1</smiles>

The ${ }^{1} \mathrm{H}$ NMR spectrum $\left[\delta\right.$ in DMSO- $\mathrm{d}_{6}$ ] showed signals at $0.98(\mathrm{t}, 6 \mathrm{H}$, $\left.J=7.0 \mathrm{~Hz}, \mathrm{CH}_{3^{-}}\right), 3.97\left(\mathrm{~d}, 2 \mathrm{H}, J=7.0 \mathrm{~Hz},-\mathrm{CH}_{2^{-}}\right), 3.98(\mathrm{~d}, 2 \mathrm{H}, J=7.0 \mathrm{~Hz}$, $\left.-\mathrm{CH}_{2}-\right), 4.53(\mathrm{~s}, 2 \mathrm{H}, \mathrm{H} 3), 5.76(\mathrm{~s}, 2 \mathrm{H}, \mathrm{H} 4), 7.24(\mathrm{~d}, 4 \mathrm{H}, J=8.8 \mathrm{~Hz}, \mathrm{H} 1)$ and $7.44(\mathrm{~d}, 4 \mathrm{H}, J=8.8 \mathrm{~Hz}, \mathrm{H} 2)$. The ${ }^{13} \mathrm{C}$ NMR spectrum $\left[\delta\right.$ in DMSO- $\left.\mathrm{d}_{6}\right]$ showed signals at $13.44,42.21,60.59,125.74,128.53,129.83,131.51,134.91,140.08$ and 166.18 p.p.m.

Analysis calculated for $\mathrm{C}_{24} \mathrm{H}_{22} \mathrm{Cl}_{2} \mathrm{O}_{4}: \mathrm{C}, 64.73 \% ; \mathrm{H}, 4.98 \%$. Found: C, $64.55 \% ; \mathrm{H}, 4.87 \%$.

\section{3,6-Di (4-chlorophenyl)-trans-1,2-dihydrophthalic acid diethyl ester (2)}

$1(4.45 \mathrm{~g}, 0.01 \mathrm{~mol})$ was added to a solution of $\mathrm{KOH}(1.00 \mathrm{~g}, 0.017 \mathrm{~mol})$ in methanol $(20 \mathrm{ml})$, and stirred at $50^{\circ} \mathrm{C}$ for $20 \mathrm{~min}$. The reaction mixture was cooled to room temperature, and poured into water $(300 \mathrm{ml})$. The precipitate was collected by filtration, and the pure 2 was obtained by recrystallization from methanol. The yield was $3.92 \mathrm{~g}(88 \%)$, while the $\mathrm{Mp}$ was $111-113^{\circ} \mathrm{C}$. The IR spectrum exhibited absorption bands at $2980 \mathrm{~cm}^{-1}, 2930 \mathrm{~cm}^{-1}\left(-\mathrm{C}_{2} \mathrm{H}_{5}\right)$, $1725 \mathrm{~cm}^{-1}(\mathrm{C}=\mathrm{O})$ and $1610 \mathrm{~cm}^{-1}(\mathrm{C}=\mathrm{C})$.

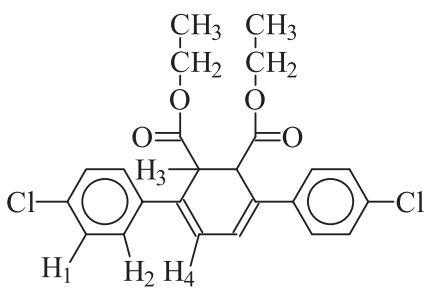

The ${ }^{1} \mathrm{H}$ NMR spectrum $\left[\delta\right.$ in DMSO- $\left.\mathrm{d}_{6}\right]$ showed signals at $1.00(\mathrm{t}, 6 \mathrm{H}$, $\left.J=7.0 \mathrm{~Hz}, \mathrm{CH}_{3^{-}}\right), 3.97\left(\mathrm{~d}, 2 \mathrm{H}, J=7.0 \mathrm{~Hz},-\mathrm{CH}_{2^{-}}\right), 3.98(\mathrm{~d}, 2 \mathrm{H}, J=7.0 \mathrm{~Hz}$, $\left.-\mathrm{CH}_{2}-\right), 4.54(\mathrm{~s}, 2 \mathrm{H}, \mathrm{H} 3), 6.57(\mathrm{~s}, 2 \mathrm{H}, \mathrm{H} 4), 7.29(\mathrm{~d}, 4 \mathrm{H}, J=8.8 \mathrm{~Hz}, \mathrm{H} 1)$ and 7.45 (d, $4 \mathrm{H}, J=8.8 \mathrm{~Hz}, \mathrm{H} 2)$. The ${ }^{13} \mathrm{C}$ NMR spectrum [ $\delta$ in DMSO- $\mathrm{d}_{6}$ ] showed signals at $13.45,42.23,66.38,125.76,128.53,129.82,131.53,134.92,140.08$ and 166.21 p.p.m.

Analysis calculated for $\mathrm{C}_{24} \mathrm{H}_{22} \mathrm{Cl}_{2} \mathrm{O}_{4}: \mathrm{C}, 64.73 \% ; \mathrm{H}, 4.98 \%$. Found: C, $64.60 \% ; \mathrm{H}, 4.85 \%$.

\section{$\mathrm{Ni}(0)$-catalyzed polymerization of 1}

A 50-ml three-necked flask equipped with a condenser tube was charged with nickel(II) bromide ( $55 \mathrm{mg}, 0.25 \mathrm{mmol})$, triphenylphosphine $(0.50 \mathrm{~g}, 1.9 \mathrm{mmol})$, zinc powder $(0.505 \mathrm{~g}, 7.72 \mathrm{mmol})$ and a magnetic stir bar. The flask was sealed with a rubber septum and placed under a dry $\mathrm{N}_{2}$ atmosphere. Freshly distilled DMF $(20 \mathrm{ml})$ was added via a syringe through the rubber septum, and the mixture was stirred at $60^{\circ} \mathrm{C}$ for $10 \mathrm{~min}$. After the mixture had turned redbrown, $1(0.94 \mathrm{~g}, 2.1 \mathrm{mmol})$ was added as a solid and the polymerization was performed at $80^{\circ} \mathrm{C}$ for $48 \mathrm{~h}$. After $\sim 16 \mathrm{~h}$, the reaction solution became yellow, followed by the precipitation of the generated yellow polymer. The reaction mixture was cooled to room temperature, and poured into acetone $(250 \mathrm{ml})$. The precipitate was collected by filtration, and washed thoroughly with $2 \mathrm{M}$ $\mathrm{HCl}$ and hot hexane. The IR spectrum exhibited absorption bands at $2980 \mathrm{~cm}^{-1}, 2930 \mathrm{~cm}^{-1}\left(-\mathrm{C}_{2} \mathrm{H}_{5}\right), 1720 \mathrm{~cm}^{-1} \quad(\mathrm{C}=\mathrm{O}), 1600 \mathrm{~cm}^{-1} \quad(\mathrm{C}=\mathrm{C})$ and $1470 \mathrm{~cm}^{-1}$ (aromatic ring). 


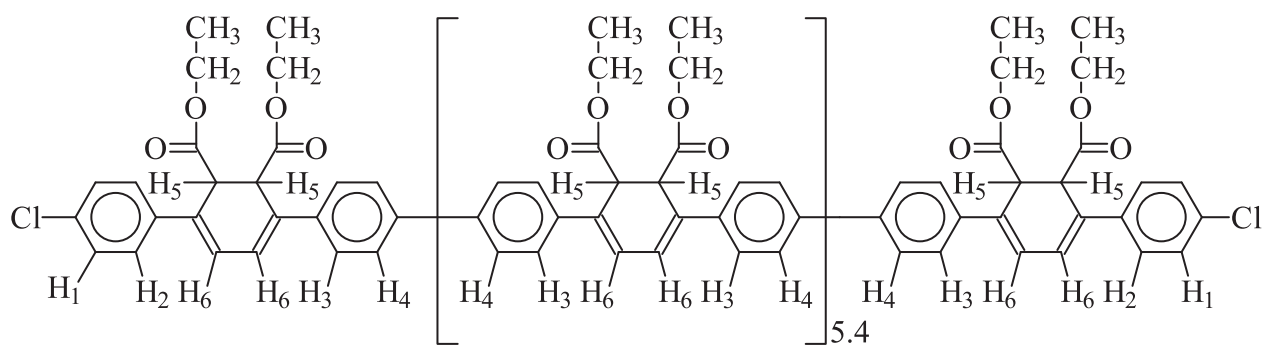

The ${ }^{1} \mathrm{H}$ NMR spectrum [ $\delta$ in DMSO- $\mathrm{d}_{6}$ ] showed signals at $0.90-1.33(6 \mathrm{H}$, $\left.\mathrm{CH}_{3}-\right)$, 3.90-4.20 (4 H, $\left.-\mathrm{CH}_{2^{-}}\right), 4.53-4.70(2 \mathrm{H}, \mathrm{H} 5), 6.74-6.92(2 \mathrm{H}, \mathrm{H} 6)$, 7.24-7.48 (1.08 H, H1 + H2) and 7.50-7.90 (6.92 H, H3 + H4).

Analysis calculated for $\mathrm{C}_{177.6} \mathrm{H}_{162.8} \mathrm{Cl}_{2} \mathrm{O}_{29.6}$ : $\mathrm{C}, 75.07 \%$; $\mathrm{H}, 5.77 \%$. Found: C, $74.75 \% ; \mathrm{H}, 5.69 \%$.

\section{$\mathrm{Ni}(0)$-catalyzed polymerization of 2}

A $50-\mathrm{ml}$ three-necked flask equipped with a condenser tube was charged with $\mathrm{NiCl}_{2}\left(\mathrm{PPh}_{3}\right)_{2}(0.16 \mathrm{~g}, 0.25 \mathrm{mmol})$, triphenylphosphine $(0.39 \mathrm{~g}, 1.5 \mathrm{mmol})$, zinc powder $(1.01 \mathrm{~g}, 15.4 \mathrm{mmol}), \mathrm{Et}_{4} \mathrm{NI}(0.96 \mathrm{~g}, 3.75 \mathrm{mmol})$ and a magnetic stir bar. The flask was sealed with a rubber septum and placed under a dry $\mathrm{N}_{2}$ atmosphere. Freshly distilled DMF $(20 \mathrm{ml})$ was added via syringe through the rubber septum, and the mixture was stirred at $60^{\circ} \mathrm{C}$ for $10 \mathrm{~min}$. After the mixture had turned red-brown, $2(0.94 \mathrm{~g}, 2.1 \mathrm{mmol})$ was added as a solid and the polymerization was performed at $80^{\circ} \mathrm{C}$ for $48 \mathrm{~h}$. After $\sim 16 \mathrm{~h}$, the reaction solution became yellow, followed by the precipitation of the generated yellow polymer. The reaction mixture was cooled to room temperature, and poured into acetone $(250 \mathrm{ml})$. The precipitate was collected by filtration, and washed thoroughly with $2 \mathrm{M} \mathrm{HCl}$ and hot hexane. The IR spectrum exhibited absorption bands at $2980 \mathrm{~cm}^{-1}, 2930 \mathrm{~cm}^{-1}$ $\left(-\mathrm{C}_{2} \mathrm{H}_{5}\right), 1720 \mathrm{~cm}^{-1}(\mathrm{C}=\mathrm{O}), 1600 \mathrm{~cm}^{-1}(\mathrm{C}=\mathrm{C})$ and $1470 \mathrm{~cm}^{-1}$ (aromatic ring). electrode was heated at $450^{\circ} \mathrm{C}$ for $30 \mathrm{~min}$ to prepare a nanoporous $\mathrm{TiO}_{2}$ thin film of $\sim 5 \mu \mathrm{m}$ thickness. The $\mathrm{TiO}_{2}$-coated ITO was soaked in a diluted NMP solution $(0.2 \mathrm{wt} \%)$ of the conjugated polymer for $12 \mathrm{~h}$, and the solvent was removed at $80^{\circ} \mathrm{C}$ to prepare the $\mathrm{ITO} / \mathrm{TiO}_{2}$ electrode modified with the conjugated polymer. The modified electrode was washed with water to remove NMP completely. The effective area of the modified $\mathrm{ITO} / \mathrm{TiO}_{2}$ electrode was adjusted to $1.0 \mathrm{~cm}^{2}$. The photocurrents were measured using a three-electrode cell consisting of the working electrode, a Pt counter electrode (Hokuto Denko Corporation, Tokyo, Japan) and saturated calomel electrode (Hokuto Denko Corporation) as the reference electrode in an electrolyte solution. Two types of solutions, an aqueous solution containing $0.8 \mathrm{M} \mathrm{NaCl}$ and an acetonitrile solution containing $0.5 \mathrm{M}$ tetrapropylammonium iodide, $0.02 \mathrm{M} \mathrm{KI}$ and $0.04 \mathrm{M} \mathrm{I}$, were used as the electrolyte solutions.

A Hokuto Denko HA-501 m potentiostat (Hokuto Denko Corporation) was employed to study the photoelectrochemical properties. An Ushio Denki $500 \mathrm{~W}$ Xe lamp (Ushio Denki Corporation, Tokyo, Japan) was used as the light source, and the Xe lamp light was monochromatized by a Shimadzu SPG100ST monochromator (Shimadzu Corporation).

\section{RESULTS AND DISCUSSION}

\section{Monomer synthesis}

3,6-Di(4-chlorophenyl)-3,6-dihydrophthalic acid diethyl ester 1 was synthesized by the Diels-Alder reaction of $(E, E) 1,4$-bis(4-chlorophe-

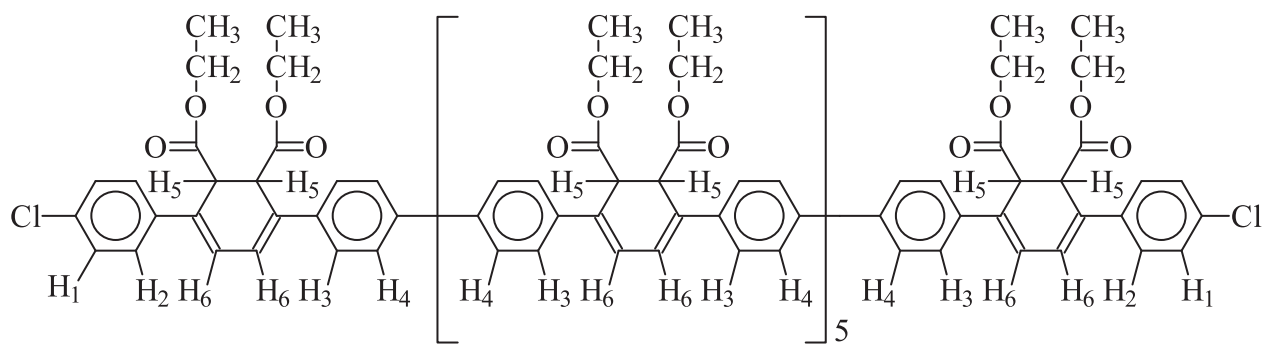

The ${ }^{1} \mathrm{H}$ NMR spectrum [ $\delta$ in DMSO- $\mathrm{d}_{6}$ ] showed signals at $0.90-1.33(6 \mathrm{H}$ $\left.\mathrm{CH}_{3}-\right)$, 3.90-4.20 (4 H, $\left.-\mathrm{CH}_{2^{-}}\right), 4.53-4.70(2 \mathrm{H}, \mathrm{H} 5), 6.74-6.92(2 \mathrm{H}, \mathrm{H} 6)$, 7.24-7.48 $(1.14 \mathrm{H}, \mathrm{H} 1+\mathrm{H} 2)$ and 7.50-7.90 $(6.86 \mathrm{H}, \mathrm{H} 3+\mathrm{H} 4)$.

Analysis calculated for $\mathrm{C}_{166} \mathrm{H}_{154} \mathrm{Cl}_{2} \mathrm{O}_{28}$ : C, $74.95 \%$; H, 5.77\%. Found: C, $74.45 \%$; H, 5.53\%.

\section{Measurements}

${ }^{1} \mathrm{H}$ and ${ }^{13} \mathrm{C}$ NMR spectra were recorded on a JNM-GSX400 FT-NMR spectrometer (JEOL, Tokyo, Japan), and IR spectra were recorded on a Shimadzu spectro-photometer IR 435 (Shimadzu Corporation, Kyoto, Japan). A Shimadzu DSC-60 (Shimadzu Corporation) and Rigaku thermal analysis station TG 8110 (Rigaku Corporation, Tokyo, Japan) were used for DSC and $\mathrm{TG}$, respectively, and measurements were made at a heating rate of $10^{\circ} \mathrm{C}$ $\min ^{-1}$ in air or nitrogen.

The photoelectrochemical properties were measured as follows. A colloidal aqueous solution of $\mathrm{TiO}_{2}$, sample P-25 (Japan Aerosil Co. Ltd, Tokyo, Japan), was spin-coated on an indium-titanium oxide (ITO) electrode (Furuuchi Chemical Corporation, Tokyo, Japan) and heated at $100{ }^{\circ} \mathrm{C}$ for $30 \mathrm{~min}$, and the $\mathrm{ITO} / \mathrm{TiO}_{2}$ nyl)-1,3-butadiene 5 (Kamigata et al. ${ }^{28}$ ) according to Scheme 2 with diethyl acetylenedicarboxylate. $\mathbf{5}$ was synthesized by a similar synthetic method to that of (E,E)-1,4-bis(phenyl)-1,3-butadiene, ${ }^{21,29-30}$ which is described in the Supplementary Information. The two 4-chlorophenyl groups are thought to lie on the same side of the 1,4-cyclohexadiene ring according to a crystal structure for 3,6-di(4-bromophenyl)-3,6-dihydrophthalic acid diethyl ester synthesized by the same method. ${ }^{31}$ subsequently, 2 was obtained by treatment of 1 with potassium hydroxide in methanol. The two ester moieties are assumed to have the trans configuration as they do in compound $3 .^{21}$

Chemical structures were confirmed by IR and NMR spectroscopies and elemental analysis. Compound 1 showed an IR absorption band at $1720 \mathrm{~cm}^{-1}$ characteristic of a carbonyl group. The ${ }^{13} \mathrm{C}$ NMR spectrum of 1 exhibited 10 peaks due to symmetry, indicating the formation of the desired structure. The ${ }^{13} \mathrm{C}$ NMR spectrum of 2 also exhibited 10 peaks. Elemental analyses of the compounds were 
<smiles>CCOC(=O)C=CC(=O)OCC</smiles>
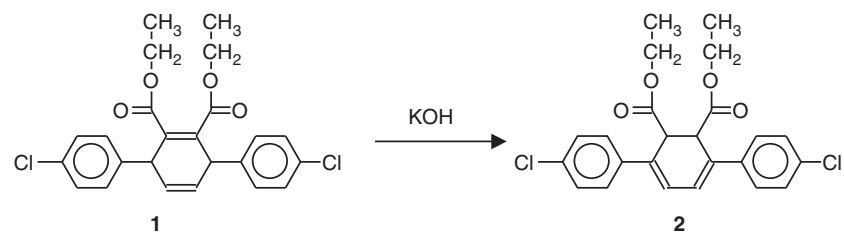

Scheme 2 Synthesis of 1 and 2 .

also in good agreement with calculated results for the proposed structures.

\section{$\mathrm{Ni}(0)$-catalyzed polymerization}

A coupling reaction by $\mathrm{Ni}(0)$ catalysts from air stable precursors was used for polymerization of $\mathbf{1}$ (Scheme 1b). The method involved the generation of the $\mathrm{Ni}(0)$ catalyst upon the addition of solvents to a mixture of the Ni (II) compound, triphenylphosphine and $\mathrm{Zn}$ under an inert atmosphere. After stirring the mixture for $5 \mathrm{~min}$, the formation of $\mathrm{Ni}(0)$ was indicated by a red-brown color. Next, 1 was added, and the reaction mixture was stirred at $80^{\circ} \mathrm{C}$ for $48 \mathrm{~h}$. The reaction solution became yellow after $\sim 16 \mathrm{~h}$, followed by the precipitation of the generated yellow polymers. After the reaction mixture was poured into acetone, the resulting precipitate was washed with $2 \mathrm{M} \mathrm{HCl}$ and hot hexane to remove $\mathrm{Zn}$ and triphenylphosphine, respectively. The solubility of the polymer was very low, dissolving only concentrations of $1 \mathrm{wt} \%$ or less, even in hot NMP, DMF, $N, N$ dimethylacetamide and dioxane. For comparison, polymerization of $\mathbf{2}$ was also performed by the coupling reaction with $\mathrm{Ni}(0)$ catalysts. In the polymerizations of $\mathbf{2}$, conjugated polymers were directly prepared (Scheme 1c).

The ${ }^{1} \mathrm{H}$ NMR spectrum of the polymer from 1 was compared with that of the polymer from 2 (Figure 1). ${ }^{1} \mathrm{H}$ NMR spectra of the starting 1 and 2 are also shown (Figure 1). In the ${ }^{1} \mathrm{H}$ NMR spectrum of the polymer from 2 (Figure $1 \mathrm{~b}$ ), the resonances attributed to 1,2protons (H5) and 4,5-protons (H6) of the diethyl 1,2-dihydrophthalate unit are observed at $\sim 4.6$ and 6.8 p.p.m., respectively. In the ${ }^{1} \mathrm{H}$ NMR spectrum (Figure 1d) of the polymer from 1, the resonances attributed to the 4,5-protons of the diethyl 3,6-dihydrophthalate unit are not observed around 5.8 p.p.m., as in starting 1; instead, resonances around 6.8 p.p.m. are observed. The ${ }^{1} \mathrm{H}$ NMR spectrum (Figure 1d) of the polymer from $\mathbf{1}$ is the same as that (Figure $1 \mathrm{~b}$ ) of the polymer from 2, and the resonances around 6.8 p.p.m. in the ${ }^{1} \mathrm{H}$ NMR spectrum of the polymer from 1 are attributed to the 4,5protons of the diethyl 1,2-dihydrophthalate unit. The conjugated polymer, whose structure is the same as that of the conjugated polymer from 2, was generated by isomerization of the 1,4-cyclohexadiene moiety into a 3,5-cyclohexadiene moiety during the polymerization of $\mathbf{1}$. The isomerization of monomer 3 to monomer 4 is reported to involve abstraction of a hydrogen ion in the benzyl position of 3 by $\mathrm{OH}^{-}$and transfer of the generated carbanion to a stable structure. ${ }^{21}$ Although $\mathrm{PPh}_{3}$ is a weak base, the polymerization of $\mathbf{1}$ is thought to be accompanied by abstraction of the benzyl proton due to the electron-withdrawing effect ${ }^{25}$ by the generated $\mathrm{Ni}(\mathrm{II})$.
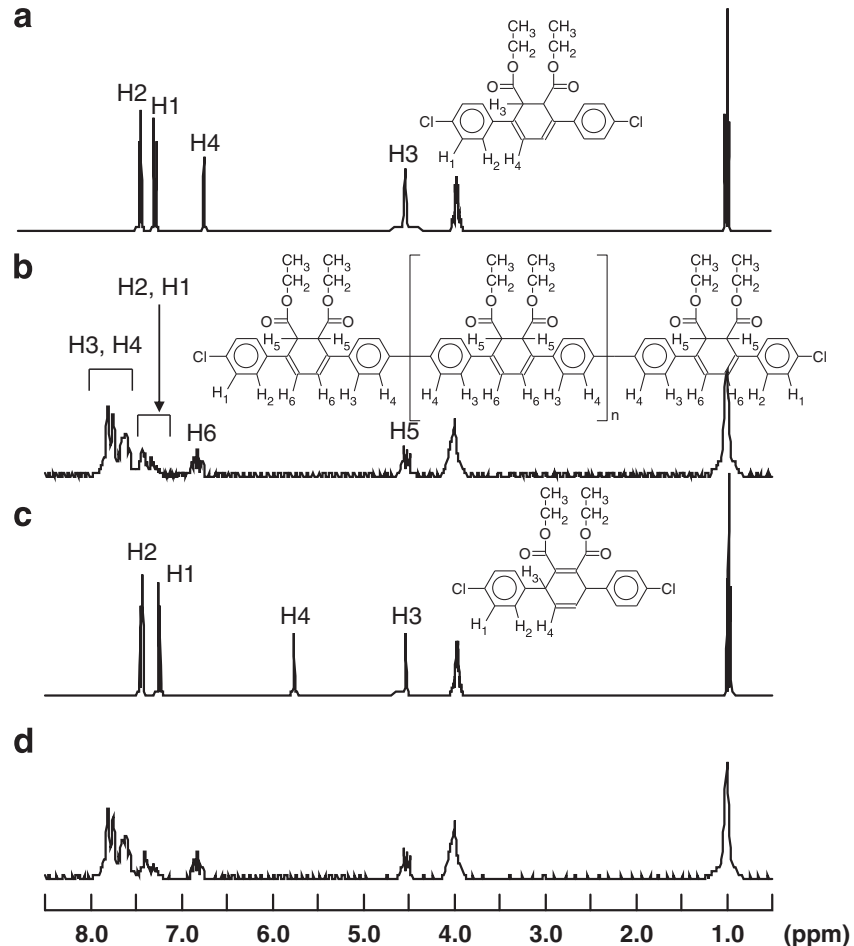

Figure $1^{1} \mathrm{H}$ NMR (nuclear magnetic resonance) spectra. (a) 2, (b) polymer from 2, (c) 1, and (d) polymer from 1 .

Number-average $\mathrm{DP}=n+2$ were determined by the ratio of aromatic protons in the terminus to those in the main chain of the conjugated polymers. In the ${ }^{1} \mathrm{H}$ NMR spectra (Figure $1 \mathrm{~b}$ and $\mathrm{d}$ ) of the conjugated polymers, the resonances at 7.24-7.48 p.p.m. are attributed to protons ( $\mathrm{H} 1$ and $\mathrm{H} 2$ ) in the terminal chlorophenyl groups, and those at 7.50-7.90 p.p.m. are attributed to protons (H3 and $\mathrm{H} 4)$ in the phenylene groups in the main chain of the conjugated polymers. The DP values were calculated from integration of the resonances. The polymerizations of 1 and 2 were examined under conditions using $\mathrm{NiCl}_{2}\left(\mathrm{PPh}_{3}\right)_{2}$ and $\mathrm{NiBr}_{2}$ as $\mathrm{Ni}(\mathrm{II})$ compounds (described in the (Supplementary Information)). The highest DP value of the polymer from 1 was 7.4, while that from 2 was 7.0. Elemental analysis values were in agreement with calculations of the DP values and the chlorines at the end of the conjugated polymers.

Figure 2 shows ultraviolet-vis absorption spectra of the conjugated polymer from 1 in DMF solution. A $\lambda_{\max }$ value is observed at $430 \mathrm{~nm}$, and the molar absorption coefficient is $1.02 \times 10^{4} \mathrm{~mol}^{-1} 1 \mathrm{~cm}^{-1}$. The spectrum of the conjugated polymer from 2 exhibits the same absorption profile. The polymer is more conjugated than unsubstituted poly $(p$-phenylene $)\left(\lambda_{\max }=380 \mathrm{~nm}\right){ }^{32}$ The energy gap between highest occupied molecular orbital (HOMO) and lowest unoccupied molecular orbital (LUMO) and the optimized structure of the conjugated polymer with $\mathrm{DP}=7$ were calculated. Density functional theory calculations were carried out with the Gaussian09W package of quantum chemical programs. The optimized structure of the conjugated polymer was obtained by the RHF/6-31G method in the gas phase. The calculated energy gap between HOMO and LUMO of the conjugated polymer was $3.03 \mathrm{eV}$, and the $\lambda_{\max }$ calculated from the energy gap value was $410 \mathrm{~nm}$, which was mostly in agreement with that of the absorption spectrum.

Figure 3 shows the optimized structure of the conjugated polymer. The average dihedral angle between the 1,4-phenylene rings was $35.5^{\circ}$, 
those between the 1,4-phenylene ring and 3,5-cyclohexadiene were $22.4^{\circ}$ and $37.7^{\circ}$, respectively, and that between the double bonds in the 3,5-cyclohexadiene moiety was $16.2^{\circ}$. The avarage dihedral angle between the 1,4-phenylene rings in $\mathrm{C}_{6} \mathrm{H}_{5}\left(\mathrm{C}_{6} \mathrm{H}_{4}\right)_{19} \mathrm{C}_{6} \mathrm{H}_{5}$ was $35.8^{\circ}$. Most of the dihedral angles in the present conjugated polymer were

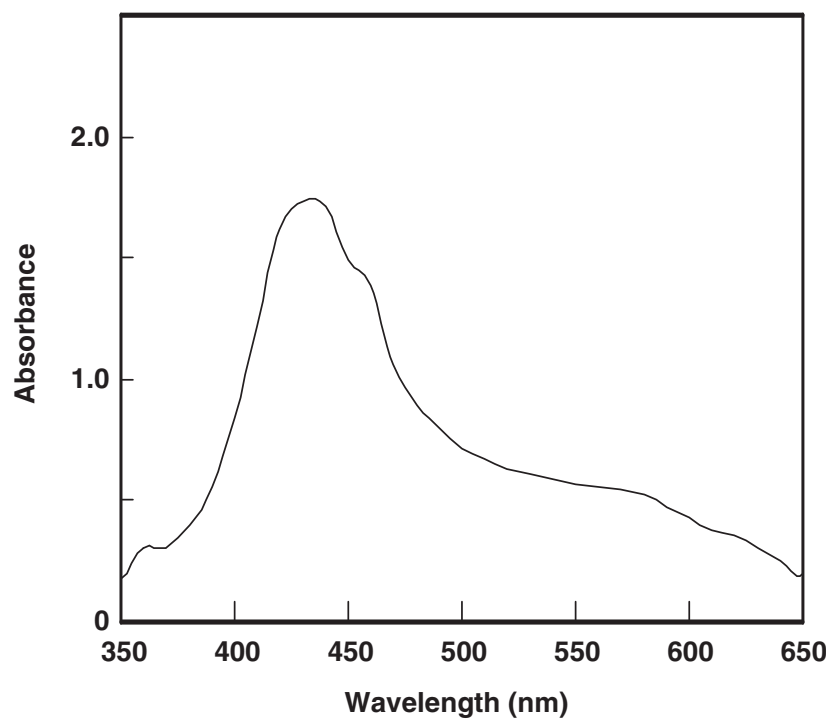

Figure 2 Ultraviolet-vis spectrum of conjugated polymer in $N, N$ dimethylformamide solution at the concentration of $4.9 \mathrm{mg}$ in $10 \mathrm{ml}$. lower than those in $\mathrm{C}_{6} \mathrm{H}_{5}\left(\mathrm{C}_{6} \mathrm{H}_{4}\right)_{19} \mathrm{C}_{6} \mathrm{H}_{5}$, and the conjugated polymer was suggested to be more planar than poly(p-phenylene). The $\lambda_{\max }$ of monomer $\mathbf{1}$ and monomer $\mathbf{2}$ in dichloromethane solution were 270 and $330 \mathrm{~nm}$, respectively.

\section{Application to photo-sensitizer of solar cell}

The $\lambda_{\max }$ is $430 \mathrm{~nm}$ in the absorption spectrum of the conjugated polymer, which is close to the $\lambda_{\max }(450 \mathrm{~nm})$ in the energy spectrum of sunlight. Therefore, the conjugated polymer was investigated as a photo-sensitizer of solar cells. The development of polymeric solar cells is accelerating with the needs of new clean energy sources. ${ }^{26,33-38}$

The ITO/TiO ${ }_{2}$ electrode, modified with the conjugated polymer by coating with the diluted NMP solution, was used as the working electrode. The photoelectrochemical properties were measured using a three-electrode cell consisting of the working electrode, a Pt counter electrode, and saturated calomel electrode as the reference electrode in an electrolyte solution. This system works as follows: (1) the conjugated polymer is excited by the irradiation of light, (2) the excited electrons are transferred to the $\mathrm{TiO}_{2}$ electrode, (3) the missing electrons in the conjugated polymer are supplied from the electrolyte, and (4) the electrolyte accepts electrons at the surface of the counter electrode. Two types of solutions, an aqueous solution containing $0.8 \mathrm{M} \mathrm{NaCl}$ and an acetonitrile solution containing $0.5 \mathrm{M}$ tetrapropylammonium iodide, $0.02 \mathrm{M} \mathrm{KI}$ and $0.04 \mathrm{M} \mathrm{I}_{2}$, were used as the electrolyte solutions.

Figure 4 shows the anodic photocurrent action spectra and the absorption spectrum of the conjugated polymer solution. The photocurrent spectra were measured without bias potentials. The fact
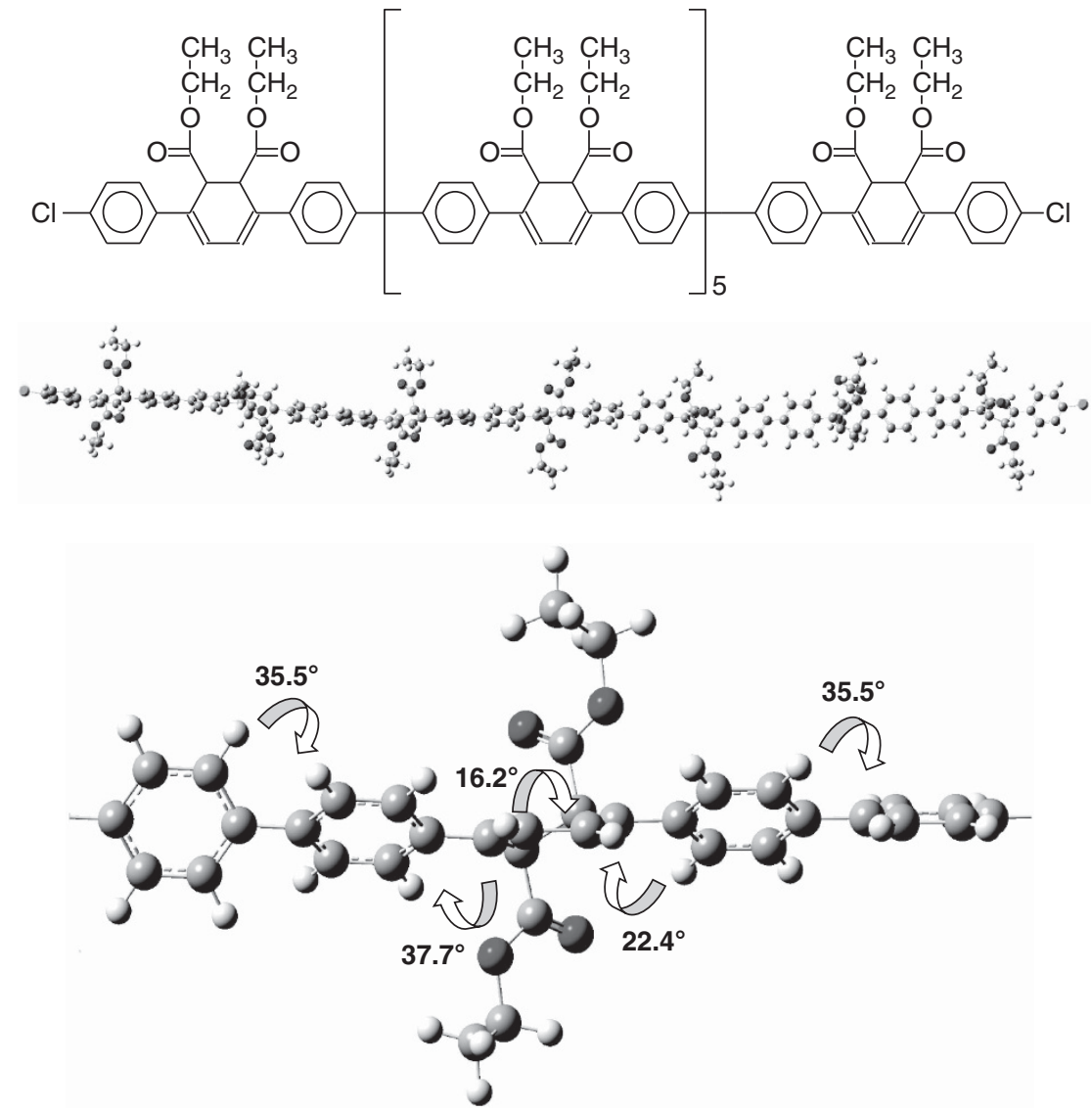

Figure 3 Optimized structure of conjugated polymer with degree of polymerization $=7$. A full color version of this figure is available at Polymer Journal online. 


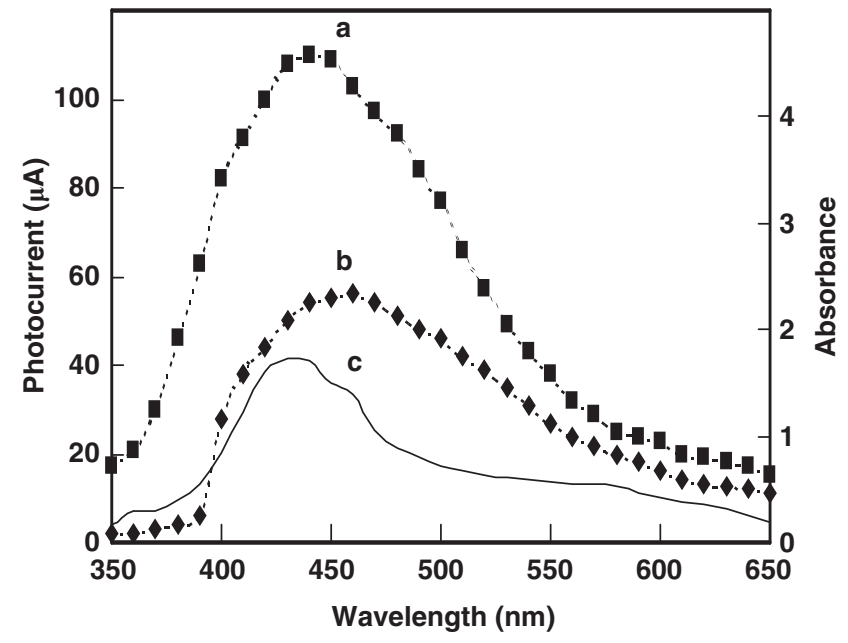

Figure 4 Photocurrent from indium-titanium oxide (ITO)/TiO2 electrode modified with the conjugated polymer and its absorption spectra. (a) Photocurrent in $\mathrm{I}_{3}-3 \mathrm{I}^{-}$electrolyte, (b) photocurrent in $\mathrm{NaCl}$ electrolyte, and (c) absorption of a $\mathrm{N}, \mathrm{N}$-dimethylformamide solution of the polymer.

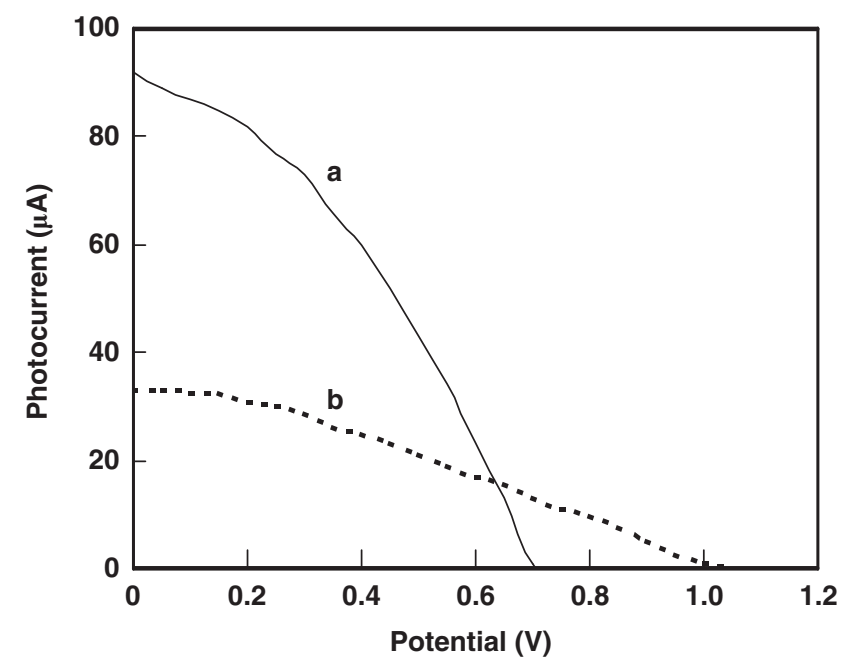

Figure 5 Photocurrent-Voltage characteristics of conjugated polymer solar cell under $450 \mathrm{~nm}$ light illumination of $4.9 \mathrm{~mW} \mathrm{~cm}^{-2}$. (a) Photocurrent in $\mathrm{I}_{3}{ }^{-}-3 \mathrm{I}^{-}$electrolyte and (b) photocurrent in $\mathrm{NaCl}$ electrolyte.

that the action spectra were very similar in shape to the absorption spectrum implied that the electrons were transferred only from the excited conjugated polymer to the $\mathrm{ITO} / \mathrm{TiO}_{2}$ electrode by the irradiation of light. The slight red-shift of the maximum peak compared with the absorption spectrum in solution may be attributed to aggregation or interaction of the polymer chains. The incident monochromatic photon $(450 \mathrm{~nm})$-to-current conversion efficiencies (IPCE), defined as the number of electrons generated by light in the external circuit divided by the number of incident photons, were $3.1 \%$ and $6.1 \%$ in the $\mathrm{NaCl}$ electrolyte and $\mathrm{I}_{3}{ }^{-}-3 \mathrm{I}^{-}$electrolyte, respectively. The lower IPCE value in the $\mathrm{NaCl}$ electrolyte is thought to be due to the generation of $\mathrm{Cl}_{2}$ in the electron transfer from $\mathrm{Cl}^{-}$to the electron-deficient conjugated polymer. The anodic photocurrent was not generated from the $\mathrm{ITO} / \mathrm{TiO}_{2}$ electrode without the conjugated polymer.

Figure 5 shows photocurrent-voltage characteristics of the cells under $450 \mathrm{~nm}$ light illumination. Open circuit voltage $\left(V_{\mathrm{oc}}\right)$ and

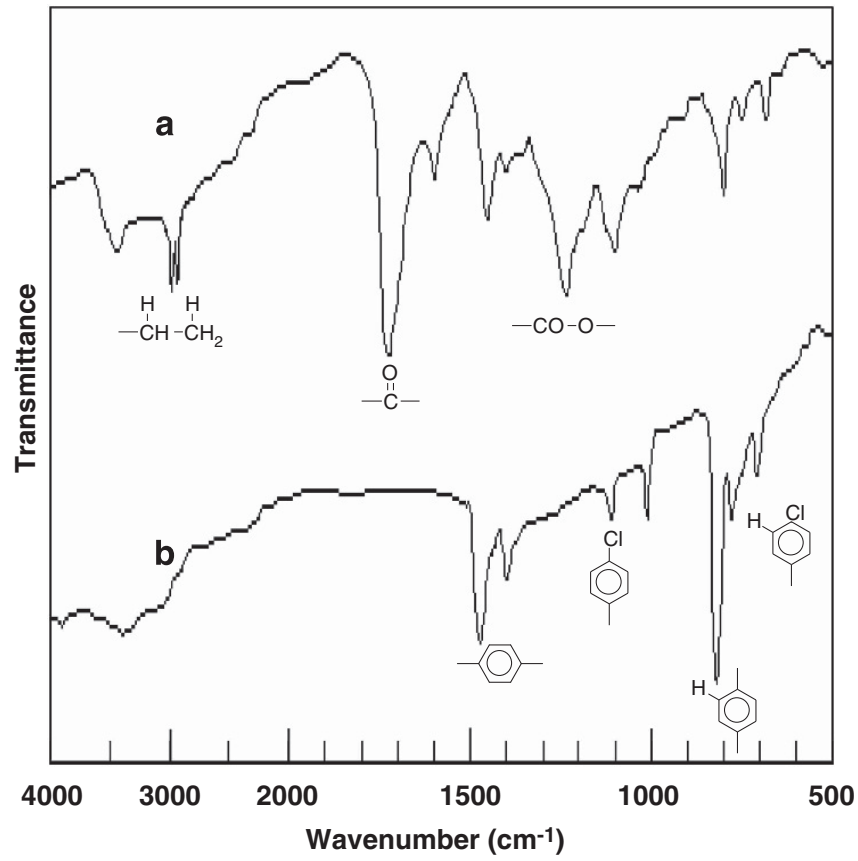

Figure 6 Infrared spectra of (a) conjugated polymer and (b) poly(phenylene) from thermal conversion of conjugated polymer.

short-circuit photocurrent $\left(i_{\mathrm{sc}}\right)$ of the cell using the $\mathrm{NaCl}$ electrolyte were $1.05 \mathrm{~V}$ and $34 \mu \mathrm{A}$, respectively, and the energy conversion efficiency $(\eta)$ was $0.21 \% . V_{\mathrm{oc}}$ and $i_{\mathrm{sc}}$ of the cell using the $\mathrm{I}_{3}{ }^{-}-3 \mathrm{I}^{-}$ electrolyte were $0.70 \mathrm{~V}$ and $92 \mu \mathrm{A}$, respectively, and $\eta$ was $0.49 \%$. The difference in the $V_{\mathrm{oc}}$ values is due to the oxidation-reduction potential of the electrolytes.

Thermal properties of the conjugated polymer and conversion to poly $(p$-phenylene)

The thermal behavior of the conjugated polymer was evaluated by TG and DSC (see the Supplementary Information for DSC and TG curves). The glass transition temperature $(\mathrm{Tg})$ was $210^{\circ} \mathrm{C}$. Weight loss, which was due to the loss of ethoxycarbonyl groups, was observed at $260{ }^{\circ} \mathrm{C}$ in both nitrogen and air. The TG profile in nitrogen shows that the conjugated polymer loses $\sim 41 \%$ of its original mass upon heating at $450{ }^{\circ} \mathrm{C}$. This weight loss is close to the value expected for complete conversion to poly(phenylene). To demonstrate that the conjugated polymer was converted to $\operatorname{poly}(p-$ phenylene), pyrolysis experiments were conducted on the powder for subsequent spectroscopic analysis. To perform the pyrolysis experiments, the powder was heated under nitrogen at $300^{\circ} \mathrm{C}$ for $1 \mathrm{~h}$, and then analyzed by IR spectroscopy. Figure 6 shows IR spectra of the conjugated polymer powder before and after heating at $300{ }^{\circ} \mathrm{C}$. In the powder heated at $300{ }^{\circ} \mathrm{C}$, the IR spectrum did not show peaks at $2980 \mathrm{~cm}^{-1}$ and $2930 \mathrm{~cm}^{-1}$ due to $\mathrm{C}-\mathrm{H}$ stretching of the ethyl group or at $1720 \mathrm{~cm}^{-1}$ and $1230 \mathrm{~cm}^{-1}$ due to the carbonyl group. A strong peak occurred at $800 \mathrm{~cm}^{-1}$, due to the $\mathrm{C}-\mathrm{H}$ out-of-plane deformation of the 1,4-disubstituted benzene ring. The peaks at $1470 \mathrm{~cm}^{-1}$ and $1400 \mathrm{~cm}^{-1}$ are due to ring stretching, and those at $780 \mathrm{~cm}^{-1}$ and $690 \mathrm{~cm}^{-1}$ are due to the C-H out-of-plane bending modes of the monosubstituted benzene end group unit. The peak at $1100 \mathrm{~cm}^{-1}$ is assigned to the $\mathrm{C}-\mathrm{Cl}$ stretching. No other IR peaks were apparent, indicating that the conjugated polymer was converted to $\operatorname{poly}(p-$ phenylene) with a regular structure. 


\section{CONCLUSIONS}

Conjugated polymers were synthesized by $\mathrm{Ni}(0)$-catalyzed coupling polymerizations of 3,6-di(4-chlorophenyl)-3,6-dihydrophthalic acid diethyl ester accompanied by isomerization of the 1,4-cyclohexadiene moiety into a 3,5-cyclohexadiene group. The conjugated polymer dissolved only at concentration of $1 \mathrm{wt} \%$ or less, even in hot organic solvents. The conjugated polymer also exhibited a $\lambda_{\max }$ at $430 \mathrm{~nm}$ in its absorption spectrum, and could be applied as a photo-sensitizer of solar cells by modifying an $\mathrm{ITO} / \mathrm{TiO}_{2}$ electrode with a dilute solution of the conjugated polymer. The conjugated polymer showed a glass transition temperature of $210^{\circ} \mathrm{C}$, and was converted by thermal treatment at $300{ }^{\circ} \mathrm{C}$ to $\operatorname{poly}(p$-phenylene) with the elimination of ethoxycarbonyl groups.

\section{CONFLICT OF INTEREST}

The authors declare no conflict of interest.

1 Kovacic, P. \& Jones, M. B. Dehydro coupling of aromatic nuclei by catalyst-oxidan systems: poly(p-phenylene). Chem. Rev. 87, 357-379 (1987).

2 Percec, V., Bae, J.-Y., Zhao, M. \& Hill, D. H. Synthesis of functional polyphenylenes from substituted hydroquinones via nickel(0)-catalyzed polymerization of their bismesylates. Macromolecules 28, 6726-6734 (1995).

3 Grob, M. C., Feiring, A. E., Auman, B. C., Percec, V., Zhao, M. \& Hill, D. H. Solubilization of regioregular and regioirregular poly(p-phenylene)s via $\mathrm{CF}_{3}$ and $\mathrm{OCF}_{3}$ Substituents to generate a model for rigid-rod polymers. Macromolecules 29, 7284 7293 (1996).

4 Kudo, M., Takimoto, C., Minami, Y., Uno, T., Itoh, T. \& Shoyama, M. Incororation of $\pi$ Conjugated polymer into silica: preparation of poly[2-methoxy-5-(2-ethylhexyloxy)-1,4phenylenevinylene]/silica and poly(3-hexylthiophene)/silica composites. Macromolecules 38, 7314-7320 (2005).

5 Chen, S. H., Su, A. C., Huang, Y. F., Su, C. H., Peng, G. Y. \& Chen, S. A Supramolecular aggregation in bulk poly(2-methoxy-5-2'-ethylhexyloxy)-1,4-phenylenevinylene). Macromolecules 35, 4229-4232 (2002).

6 Yokazawa, T., Suzuki, R., Nojima, M., Ohta, Y. \& Yokoyama, A. Precision synthesis of poly(3-hexylthiophene) from catalyst-transfer suzuki-miyaura coupling polymerization. Macromol. Rapid. Commun. 32, 801-804 (2011).

7 Higashihara, T., Goto, E. \& Ueda, M. Purification-free and protection-free synthesis of regioregular poly(3-hexylthiophene) and poly(3-(6-hydroxyhexyl)thiophene) using a zincate complex of ${ }^{t} \mathrm{Bu}_{4} \mathrm{ZnLi}_{2}$. Macromol. Lett. 1, 167-170 (2012).

8 Cassidy, P. E., Marvel, C. S. \& Ray, S. Preparation and aromatization of poly-1,3 cyclohexadiene and subsequent crosslinking III. J. Polym. Sci 3, 1553-1565 (1965).

9 Marvel, C. S. \& Hartzel, G. C. Preparation and aromatization of Poly-1,3-cyclohexadiene. J. Am. Chem. Soc. 81, 448-452 (1959).

10 Natori, I., Natori, S. \& Sato, H. Synthesis of soluble polyphenylene homopolymers as polar macromolecules: complete dehydrogenation of poly(1,3-cyclohexadiene) with controlled polymer chain structure. Macromolecules 39, 3168-3174 (2006).

11 Gin, D. L., Conticello, V. P. \& Grubbs, R. H. Stereoregular precursors to poly( $p$ phenylene) via transition-metal-catalyzed polymerizarion. 1. precursor design and synthesis. J. Am. Chem. Soc. 116, 10507-10519 (1994).

12 Ballard, D. G. H., Courtis, A., Shirley, I. M. \& Taylor, S. C. Synthesis of Polyphenylene from a cis-dihydrocatechol, a biologically produced monomer. Macromolecules 21, 294-304 (1988).

13 Gin, D. L., Conticello, V. P. \& Grubbs, R. H. Stereoregular precursors to poly( $p$ phenylene) via Transition-metal-catalyzed polymerizarion. 2. The effects of polymer stereochemistry and acid catalysts on precursor aromatization: a characterization study. J. Am. Chem. Soc. 116, 10934-10947 (1994).

14 Gilch, H. G. \& Wheelwright, W. L. Polymerization of $\alpha$-halogenated $p$-xylenes with base. J. Polym. Sci. 4, 1337-1349 (1966).

15 Banishoeib, F., Adriaensens, P., Berson, S., Guillerez, S., Douheret, O., Manca, J. Fourier, S., Cleij, T. J., Lutsen, L. \& Vanderzande, D. The synthesis of region-regular poly(3-alkyl-2,5-thienylene vinylene) derivatives using lithium bis(trimethylsilyl)amide(LHMDS) in the dithiocarbamate precursor rout. Solar Energ. Mater. Solar Cells 91 1026-1034 (2007)

16 Banishoeib, F., Henckens, A., Fourier, S., Vanhooyland, G., Breselge, M., Manca, J., Cleij, T. J., Lutsen, L., Vanderzande, D., Nguyen, L. H., Neugebaucer, H. \& Sariciftci, N. S. Synthesis of poly(2,5-Thienylene Vinylene) and its derivatives: low band gap materials for photovaltacs. Thin Solid Films $\mathbf{5 1 6}$ 3978-3988 (2008)

17 Son, S., Dodabalapur, A., Lovinger, A. J. \& Galvin, M. E. Luminescence enhancement by the introduction of disorder into poly( $p$-phenylene vinylene). Science 269, 376-378 (1995).

18 Louwet, F., Vanderzande, D. \& Gelan, J. The synthesis of poly(1,4-phenylene-1,2ethanediyl) derivatives: an adaptation of the wessling route. Synth. Met. 52, 125-130 (1992).

19 Louwet, F., Vanderzande, D. \& Gelan, J. A general synthetic route to high molecular weight poly(p-xylylene)-derivatives: a new route to poly(p-phenylene vinylene). Synth. Met. 69, 509-510 (1995).

20 Louwet, F., Vanderzande, D., Gelan, J. \& Mullens, J. A. New synthetic route to soluble high molecular weight precursor for poly(phenylenevinylene) derivatives. Macromolecules 28, 1330-1331 (1995).

21 Fieser, L. F. \& Haddadin, M. J. Oxidative decarboxylation. J. Am. Chem. Soc. 86, 2392-2395 (1964)

22 Chaturvedi, V., Tanaka, S. \& Kaeriyama, K. Preparation of poly( $p$-phenylene) via processable precursors. J. Chem. Soc. Chem. Commun. 1658-1659 (1992).

23 Colon, I. \& Kelsey, D. R. Coupling of aryl chlorides by nickel and reducing metals. J. Org. Chem. 51, 2627-2637 (1986).

24 Cotton, F. A., Faut, O. D. \& Goodgame, D. M. L. Preparation, spectra and electronic structures of tetrahedral nickel(II) complexes containing triphenylphosphine and halide ions as ligands. J. Am. Chem. Soc. 83, 344-351 (1961).

25 Yamamoto, T. Synthesis of $\pi$-conjugated polymers by organometallic polycondensation. Bull. Chem. Soc. Jpn 83, 431-455 (2010).

26 Yamamoto, T. $\pi$-conjugated polmers with electronic and optical functionalities: preparation by organometallic polycondensation, properties, and applications. Macromol. Rapid Commun. 23, 583-606 (2002).

27 Nazeerruddin, M., Kay, A. K., Rodicio, I., Humphry-Baker, R., Muller, E., Liska, P. Vlachopoulos, N. \& Gratzel, M. Conversion of light to electricity by cis- $\mathrm{X}_{2} \mathrm{Bis}\left(2,2^{\prime}-\right.$ bipyridyl-4,4'-dicarboxylate)ruthenium(II) charge-transfer sensitizers $\left(X=\mathrm{Cl}^{-}, \mathrm{Br}, \mathrm{I}^{-}\right.$ $\mathrm{CN}^{-}$, and $\mathrm{SCN}^{-}$) on nanocrystalline $\mathrm{TiO}_{2}$ electrodes. J. Am. Chem. Soc. 115, 6382-6390 (1993)

28 Kamigata, N., Ozaki, J. \& Kobayashi, M. A novel synthesis of (E,E)-1,4-diaryl-1,3 butadienes by the ruthenium (II) catalyzed reaction of (E)-2-arylethenesulfonul chlorides with vinylarenes. Chem. Lett. 705-708 (1985).

29 Friedrich, K. \& Henning, H. G. Darstellung Stilbenartigar Verbindungen nach der Method von G. Wittig. Chem. Ber. 92, 2944-2952 (1959).

30 Lohaus, H. Eine Dien-synthese mit Acetylen-dicarbosaure-diathylester. Liebigs Ann. Chem. 516, 295-297 (1935).

31 Mattew, C. D. \& Thomas, J. G. Synthesis of p-quinquephenyl from E, E-1,4-bis(4 bromophenyl)-1,3-butadiene. Syn. Commun. 41, 206-218 (2011).

32 Froyer, G., Goblot, J. Y., Guilbert, J. L., Maurice, F. \& Pelous, Y. Poly(Para Phenylene): some properties related to the synthesis method. Journal de physique. J. Phys Colloques 44, 745-748 (1983).

33 Lai, Y. C., Higashihara, T., Hsu, J. C., Ueda, M. \& Chen, W.-C. Enhancement of power conversion efficiency and long-term stability of P3HT/PCBM solar cells using C60 derivatives with thiophene units as surfactants. Solar Energ. Mater. Solar Cells 97 164-170 (2012)

34 Cai, W., Gong, X. \& Cao, Y. Polymer solar cells: Recent development and possible rout for improvement in the performance. Solar Energ. Mater. Solar Cells 94, 114-127 (2010).

35 Marumoto, K., Takeuchi, N. Ozaki, T. \& Kuroda, S. ESR studies of photogenerated polarons in regioregular poly(3-alkylthiophene)-fullerene composite. Synth. Met. 129, 239-247 (2003)

36 Brabac, C. J., Sariciftci, N. S. \& Hummelen, J. C. Plastic Solar Cells. Adv. Funct. Mater. 11, 15-26 (2001).

$37 \mathrm{Lu}$, M. D. \& Yang, S. M. Synthesis of poly(3-hexylthiophene) grafted TiO2 nanotube composite. J. Colloid Interface Sci. 333, 128-134 (2009).

38 Gu, Z., Tan, Y., Tsuchiya, K., Shimomura, T. \& Ogino, K. Synthesis and characterization of poly(3-hexylthiophene)-b-polystylene for photovoltaic application. Polymers 3, 558-570 (2011).

Supplementary Information accompanies the paper on Polymer Journal website (http://www.nature.com/pj) 